\title{
Preservation of terrestrial organic carbon in marine sediments offshore Taiwan: mountain building and atmospheric carbon dioxide sequestration
}

\author{
S.-J. Kao ${ }^{1,2}$, R. G. Hilton ${ }^{3}$, K. Selvaraj ${ }^{1,2}$, M. Dai ${ }^{2}$, F. Zehetner ${ }^{4}$, J.-C. Huang ${ }^{5}$, S.-C. Hsu ${ }^{1}$, R. Sparkes ${ }^{6}$, J. \\ T. Liu ${ }^{7}$, T.-Y. Lee ${ }^{1}$, J.-Y. T. Yang ${ }^{2}$, A. Galy ${ }^{6}$, X. Xu' ${ }^{8}$, and N. Hovius ${ }^{9}$ \\ ${ }^{1}$ Research Center for Environmental Changes, Academia Sinica, Taipei, Taiwan \\ ${ }^{2}$ State Key Laboratory of Marine Environmental Science, Xiamen University, Xiamen, China \\ ${ }^{3}$ Department of Geography, Durham University, Durham, UK \\ ${ }^{4}$ Institute of Soil Research, University of Natural Resources and Life Sciences, Vienna, Austria \\ ${ }^{5}$ Department of Geography, National Taiwan University, Taipei, Taiwan \\ ${ }^{6}$ Department of Earth Sciences, University of Cambridge, Cambridge, UK \\ ${ }^{7}$ Institute of Marine Geology and Chemistry, National Sun Yat-sen University, Kaohsiung, Taiwan \\ ${ }^{8}$ School of Physical Sciences, University of California, Irvine, CA, USA \\ ${ }^{9}$ Geomorphology, GFZ German Research Centre, Telegrafenberg, Potsdam, Germany
}

Correspondence to: S.-J. Kao (sjkao@gate.sinica.edu.tw, sjkao@xmu.edu.cn)

Received: 22 June 2013 - Published in Earth Surf. Dynam. Discuss.: 17 July 2013

Revised: 8 January 2014 - Accepted: 6 February 2014 - Published: 4 March 2014

\begin{abstract}
Geological sequestration of atmospheric carbon dioxide $\left(\mathrm{CO}_{2}\right)$ can be achieved by the erosion of organic carbon (OC) from the terrestrial biosphere and its burial in long-lived marine sediments. Rivers on mountain islands of Oceania in the western Pacific have very high rates of OC export to the ocean, yet its preservation offshore remains poorly constrained. Here we use the OC content $\left(\mathrm{C}_{\text {org }}, \%\right)$, radiocarbon $\left(\Delta^{14} \mathrm{C}_{\mathrm{org}}\right)$ and stable isotope $\left(\delta^{13} \mathrm{C}_{\mathrm{org}}\right)$ composition of sediments offshore Taiwan to assess the fate of terrestrial OC, using surface, sub-surface and Holocene sediments. We account for rock-derived OC to assess the preservation of OC eroded from the terrestrial biosphere and the associated $\mathrm{CO}_{2}$ sink during flood discharges (hyperpycnal river plumes) and when river inputs are dispersed more widely (hypopycnal). The $\mathrm{C}_{\mathrm{org}}, \Delta^{14} \mathrm{C}_{\text {org }}$ and $\delta^{13} \mathrm{C}_{\text {org }}$ of marine sediment traps and cores indicate that during flood discharges, terrestrial OC can be transferred efficiently down submarine canyons to the deep ocean and accumulates offshore with little evidence for terrestrial OC loss. In marine sediments fed by dispersive river inputs, the $\mathrm{C}_{\text {org }}, \Delta{ }^{14} \mathrm{C}_{\text {org }}$ and $\delta^{13} \mathrm{C}_{\text {org }}$ are consistent with mixing of terrestrial OC with marine $\mathrm{OC}$ and suggest that efficient preservation of terrestrial $\mathrm{OC}(>70 \%)$ is also associated with hypopycnal delivery. Sub-surface and Holocene sediments indicate that this preservation is long-lived on millennial timescales. Re-burial of rock-derived OC is pervasive. Our findings from Taiwan suggest that erosion and offshore burial of $\mathrm{OC}$ from the terrestrial biosphere may sequester $>8 \mathrm{TgC} \mathrm{yr}^{-1}$ across Oceania, a significant geological $\mathrm{CO}_{2}$ sink which requires better constraint. We postulate that mountain islands of Oceania provide a strong link between tectonic uplift and the carbon cycle, one moderated by the climatic variability which controls terrestrial OC delivery to the ocean.
\end{abstract}

1

Photosynthesis sequesters $\mathrm{CO}_{2}$ within living matter as organic carbon (OC). If a fraction of this productivity escapes respiratory consumption and oxidation, it represents a carbon sink that will reduce greenhouse gas concentrations and influence Earth's radiation energy balance (Sundquist, 1993; Stallard, 1998; Berner, 2006). On geological timescales, the 
burial of OC in marine sediments is the second largest sink of atmospheric $\mathrm{CO}_{2}$ after carbonate deposition formed from the products of continental silicate weathering (Gaillardet et al., 1999; Hayes et al., 1999, Burdige 2005). The erosion of terrestrial OC and its delivery by rivers to the ocean along with clastic sediments is thought to contribute approximately half of this oceanic OC burial flux (Schlunz and Schneider, 2000; Burdige, 2005; Blair and Aller, 2012), in part because the efficiency of OC burial is closely related to the accumulation rate of the accompanying sediment (Canfield, 1994; Burdige, 2005; Galy et al., 2007a). Therefore $\mathrm{CO}_{2}$-sequestration by OC burial may be sensitive to changes in tectonic and climatic conditions which regulate the erosion and transfer of clastic sediment and terrestrial OC by rivers (Dadson et al., 2003; Hilton et al., 2008, 2012; Milliman and Farnsworth, 2011), giving rise to feedbacks in the global carbon cycle (West et al., 2005) which are not represented in current models of the carbon cycle (Berner, 2006).

The Himalayan orogeny is thought to exert tectonic forcing on the carbon cycle (Gaillardet and Galy, 2008), sequestering $3.7 \pm 0.4 \mathrm{TgC} \mathrm{yr}^{-1}$ through erosion of recently photosynthesized OC sourced from vegetation and soil in the terrestrial biosphere $\left(\mathrm{OC}_{\text {biosphere }}\right)$ and its preservation and burial in the distant Bengal Fan (France-Lanord and Derry, 1997; Galy et al., 2007a). On mountain islands of Oceania (Taiwan, Philippines, Indonesia, Papua New Guinea and New Zealand), where land-ocean linkages are strong, small mountain rivers drain a larger combined source area than the Himalaya $\left(\sim 2.7 \times 10^{6} \mathrm{~km}^{2}\right.$ vs. $\left.1.6 \times 10^{6} \mathrm{~km}^{2}\right)$. These rivers transport $\sim 7000 \mathrm{Tg} \mathrm{yr}^{-1}$ of clastic sediment (Milliman and Farnsworth, 2011) and an estimated $20-40 \%$ of the global particulate OC flux to the oceans (Lyons et al., 2002). There, convergent plate margins have steep, high standing topography where erosion of $\mathrm{OC}_{\text {biosphere }}$ occurs at very high rates (up to $\sim 70 \mathrm{MgC} \mathrm{km}^{-2} \mathrm{yr}^{-1}$ ) and rivers can deliver particulate materials rapidly to the ocean across short floodplains (Dadson et al., 2003; Dadson et al., 2005; Scott et al., 2006; Hilton et al., 2008; Bass et al., 2011; Hilton et al., 2012). These conditions should be conducive to high rates of OC burial and higher OC preservation efficiencies than rivers draining passive margins (Galy et al., 2007a; Bianchi, 2011; Blair and Aller, 2012). However, unlike the Himalayan system, our understanding of the fate of $\mathrm{OC}_{\text {biosphere }}$ offshore and the resultant $\mathrm{CO}_{2}$ sequestration around these ocean islands remains incomplete (Eglinton, 2008).

Firstly, the incomplete understanding of $\mathrm{OC}_{\text {biosphere }}$ burial reflects the challenge of accounting for "petrogenic" OC derived from sedimentary rocks $\left(\mathrm{OC}_{\text {petro }}\right)$ in river sediments and marine sediments (Blair et al., 2003) which can contribute significantly to the particulate load of mountain rivers (Kao and Liu, 1996; Komada et al., 2004; Leithold et al., 2006; Hilton et al., 2010; Clark et al., 2013). OC petro transfer and re-burial lengthens the residence time of $\mathrm{OC}$ in the lithosphere (Galy et al., 2008; Hilton et al., 2011), however the reburial of $\mathrm{OC}_{\text {petro }}$ does not represent recent atmospheric $\mathrm{CO}_{2}$ and so must be quantified separately. Secondly, it reflects the difficultly of assessing the range of delivery mechanisms to the ocean by mountain rivers. During floods, high suspended sediment concentrations $\left(>40 \mathrm{~g} \mathrm{~L}^{-1}\right)$ can cause the density of the river outflow to surpass that of ambient seawater (hyperpycnal) and result in density currents transporting sediment down submarine canyons into the deep ocean (Mulder and Syvitski, 1995). Previous work has postulated that hyperpycnal discharges are essential for the efficient transfer of terrestrial OC into marine deposits offshore mountain islands (Kao et al., 2006; Hilton et al., 2008). However, large amounts of terrestrial $\mathrm{OC}$ and sediment are also delivered to the surface ocean by rivers in hypopycnal plumes with a density lower than seawater. Such plumes disperse fluvial materials over a larger region, which may result in re-suspension and reworking of terrestrial OC (Mulder and Syvitski, 1995; Dadson et al., 2005; Kao and Milliman, 2008). In analogy with passive margin settings, this may lower terrestrial OC burial efficiency (Aller et al., 1996; Aller, 1998; Aller and Blair, 2006; Sampere et al., 2008; Blair and Aller, 2012).

In order to shed some light on the fate of $\mathrm{OC}_{\text {biosphere }}$ eroded from high standing ocean islands, we consider the mountain island of Taiwan (Fig. 1). In Taiwan, the rapid convergence of the Philippine Sea Plate with the Eurasian continental margin combines with a climate characterized by frequent tropical cyclones, driving high rates of fluvial sediment export to the ocean (Dadson et al., 2003; Kao and Milliman, 2008). Findings from Taiwan are of wider relevance because the steep mountain rivers draining this island are common throughout Oceania (Milliman and Farnsworth, 2011). Steep mountain rivers have short transit times (e.g. Hilton et al., 2008) and deliver most of their sediment loads $(\sim 60-70 \%)$ under hypopycnal conditions (Dadson et al., 2005; Kao and Milliman, 2008). However, Taiwan's rivers can also produce hyperpycnal plumes (Dadson et al., 2005) allowing us to study terrestrial OC transfer and preservation associated with both modes of fluvial delivery. To assess the offshore transfer of terrestrial $\mathrm{OC}$ and its preservation in marine sediments upon deposition, we have collected seafloor sediments and material from sediment traps from (i) the submarine Gaoping Canyon off Southwest Taiwan, which is prone to hyperpycnal inputs; and (ii) the Okinawa Trough, Taiwan Strait and the Gaoping Shelf where hypopycnal inputs are thought to be more important (Fig. 1). To assess longer-term terrestrial OC preservation and burial, we examine sub-surface sediments from these locations and Holocene sediments from the Okinawa Trough. Employing an established approach, we have measured the OC content, stable OC isotopes and radiocarbon content of OC to determine sources of OC in the sediments and to assess the preservation of terrestrial $\mathrm{OC}_{\text {biosphere }}$ and $\mathrm{OC}_{\text {petro }}$ offshore (e.g. Komada et al., 2004; Leithold et al., 2006; Galy et al., 2007a, 2008; Hilton et al., 2008, 2010; Blair et al., 2010). The findings from Taiwan are placed in a regional context, and their implications for the global carbon cycle are discussed. 


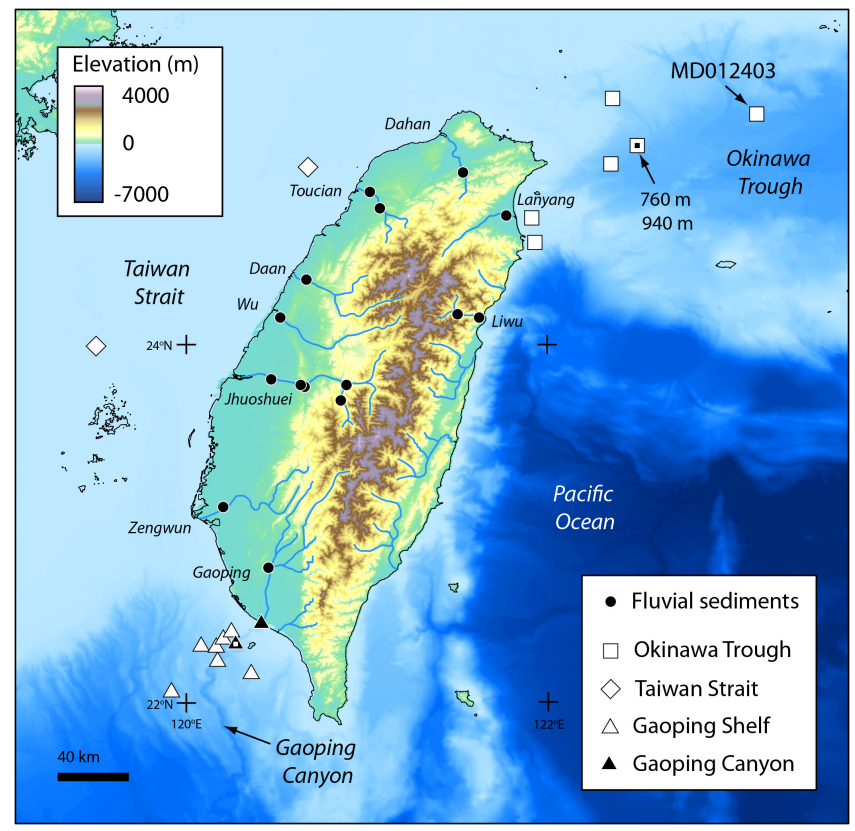

Figure 1. Location of terrestrial and marine samples from Taiwan and the surrounding ocean used in this study. River sediments were collected during typhoon floods across the island (black circles) with the sampled river names indicated (Table S1). Marine samples fed by dispersive fluvial inputs (white symbols) were obtained from box core surface sediments, with the location of the longer piston core MD012403 indicated. Sediments were also acquired from within the Gaoping Canyon (black triangles), which is fed by hyperpycnal river plumes. Sediment traps (indicated by squares within symbols) were deployed in the Okinawa Trough (depths provided) and at $608 \mathrm{~m}$ in the channel of the Gaoping Canyon.

\section{Materials and methods}

\subsection{River suspended sediment samples}

To characterize the composition of OC input into the ocean by Taiwanese rivers, suspended sediment samples were collected for this study from the primary rivers (Fig. 1) under common flow conditions as well as during tropical cycloneinduced floods, covering water discharges ranging from $<1$ to $\sim 40$ times the long-term average (Table S1), and then complemented with published data (Kao and Liu, 1996; Hilton et al., 2008). For each sample, a known volume (between $250 \mathrm{~mL}$ and $1 \mathrm{~L}$ ) of river water was collected from the surface of the main river channel in a wide-mouthed plastic bottle thoroughly rinsed with river water. The sample was then filtered through $0.7 \mu \mathrm{m} \mathrm{GF} / \mathrm{F}$ membrane filters and the contents were dried at $60^{\circ} \mathrm{C}$, weighed to determine total suspended sediment concentration (SSC, $\mathrm{gL}^{-1}$ ) and stored in sealed glass dishes. Water discharge $\left(Q_{\mathrm{w}}, \mathrm{m}^{3} \mathrm{~s}^{-1}\right)$ was measured by the Water Resources Agency, Taiwan, and reported here where available (Table S1).

\subsection{Marine sediment samples}

To assess the fate of terrestrial OC delivered to the ocean by hyperpycnal discharges, a sediment trap mooring was deployed at $608 \mathrm{~m}$ water depth, $42 \mathrm{~m}$ above the seafloor, in the submarine Gaoping Canyon, fed by the Gaoping River (Fig. 1). Full details of the collection methods can be found elsewhere (Huh et al., 2009; Liu et al., 2012, 2013). Briefly, the sediment trap mooring and an upward-facing long-range acoustic Doppler profiler were moored in the canyon during the 2008 typhoon season. The mooring was configured with a non-sequential sediment trap, consisting of a conical funnel and core liner, and an intervalometer timer capable of inserting Teflon discs into the collected sediment as embedded time markers (Xu et al., 2010). During deployment, Typhoon Kalmaegi impacted Taiwan (17 July 2008) and the Teflon discs inserted before its landfall and after the flood waters had ceased allowed us to constrain sediment associated with the typhoon event (Liu et al., 2012). Conical sediment traps may result in conservative estimates of accumulation rate due to potential re-suspension of sediment in the funnel (Buesseler et al., 2007). Here we do not rely on accumulation rate data, but note that hydrodynamic sorting may result in a lower percentage of smaller, more buoyant particles present in the trap than the sediment plume during high current velocities. To assess longer-term preservation, a box core was collected by R/V Ocean Researcher-1 in September and October 2009 at station K1 (160 m water depth), located at the thalweg of the Gaoping Canyon (Fig. 1). The core was sub-sampled at different depths (Table S2). The sediments are thought to represent deposits associated with hyperpycnal river discharge during Typhoon Morakot in August 2009 (Sparkes, 2012; Liu et al., 2013), whose exceptionally heavy rainfall in Taiwan triggered a very large number of landslides (West et al., 2011) and high rates of sediment delivery offshore (Carter et al., 2012). Together, these marine sediments allow us to assess the transfer and deposition of terrestrial materials by river hyperpycnal flows.

To assess the fate of terrestrial OC delivered by more dispersive events (hypopycnal discharges), sediments were collected from marine trap moorings at 760 and $940 \mathrm{~m}$ in the southern Okinawa Trough (Fig. 1), where direct hyperpycnal river discharges are less common (Dadson et al., 2005; Hsu et al., 2006; Kao and Milliman, 2008). In addition, seafloor sediment samples collected between 1994 and 2009 with a box corer on R/V Ocean Researcher-1 and -2 from the Gaoping Shelf, southern Okinawa Trough and Taiwan Strait were selected (Table S3). Samples were collected from the top $2 \mathrm{~cm}$ of these cores using a stainless steel spatula and freeze-dried. We have also examined Holocene sediments in the long piston core MD012403 collected by R/V Marion Dufresne in 2001 from a water depth of $1420 \mathrm{~m}$ (Kao et al., 2008). The depositional age of these sediments was determined by analysis of the radiocarbon content of planktonic foraminifera so the $\Delta^{14} \mathrm{C}_{\text {org }}$ at time of deposition can be estimated (Kao et al., 
2008). The methods of sampling terrestrial and marine sediments mean that the study focuses on the transfer and offshore preservation of sand and finer materials. Large woody debris (e.g. logs and trunks) are not likely to be recovered and so their fate remains a question for future research.

\subsection{Geochemical methods}

All marine samples were rinsed with deionized water $(>18 \mathrm{M} \Omega)$ to remove salts. All dried sediment samples were homogenized in an agate mortar. Prior to measurement of the OC concentration $\left(\mathrm{C}_{\mathrm{org}}, \%\right)$ and analysis of the stable isotopes of OC $\left(\delta^{13} \mathrm{C}_{\text {org }}, \% o\right)$, samples were treated with $1 \mathrm{~N}$ $\mathrm{HCl}$ at $20^{\circ} \mathrm{C}$ for $16 \mathrm{~h}$ to remove carbonate; the residue was centrifuged and freeze-dried (Kao et al., 2008). $\delta^{13} \mathrm{C}_{\text {org }}$ analysis was carried out using Carlo-Erba 2100 elemental analyser connected to a Thermo Finnigan Deltaplus Advantage isotope ratio mass spectrometer and reported in $\delta$ notation with respect to the PDB standard and renormalized based on working standards (USGS 40 and acetanilide), with reproducibility better than $0.2 \%$. Radiocarbon $\left({ }^{14} \mathrm{C}\right)$ was measured on $\mathrm{OC}$ by accelerator mass spectrometry after carbonate removal and graphitization at Woods Hole Oceanographic Institution, USA, Institute of Geological and Nuclear Sciences, New Zealand, and Keck-Carbon Cycle AMS Facility at University of California at Irvine, USA. ${ }^{14} \mathrm{C}$ values are given after correction for ${ }^{13} \mathrm{C}$ fractionation (normalization to a $\delta^{13} \mathrm{C}$ value of $-25 \%$ ), and expressed as percent modern carbon (pMC) comparative to $95 \%$ of the ${ }^{14} \mathrm{C}$ activity of the NBS oxalic acid and $\Delta{ }^{14} \mathrm{C}$ based on established protocols (Stuiver and Polach, 1977), with precision typically better than 10\%. Samples from the Liwu River in 2004 were analysed by similar methods described elsewhere (Hilton et al., 2008). Inorganic carbon removal by $\mathrm{HCl}$ leaching was preferred over $\mathrm{HCl}$ vapour to ensure complete removal of dolomite (Galy et al., 2007b), which may be present in Taiwanese bedrock and river sediments (Hilton et al., 2010). As such, following previous work, all OC isotope measurements refer to the acid-insoluble OC (Galy et al., 2007b; Hilton et al., 2010). The deviation between these two methods for terrestrial materials, $\delta^{13} \mathrm{C}_{\text {org }} \sim \pm 0.2 \%$ and $\Delta^{14} \mathrm{C}_{\text {org }} \sim \pm 10 \%$ o (Komada et al., 2008), was similar to the precision of the analyses.

\subsection{Terminology}

Previous work quantifying OC transfers from Taiwan and other orogenic belts has used the term "fossil" OC to define OC derived from sedimentary rocks (Kao and Liu, 2000; Galy et al., 2007a; Hilton et al., 2008, 2011; Clark et al., 2013). This is identical to the term $\mathrm{OC}_{\text {petro, }}$ with "petrogenic" used here because of its unambiguous reference to rock-derived OC (Galy et al., 2008). The term "non-fossil" $\mathrm{OC}$ has been used to refer to $\mathrm{OC}$ derived from vegetation and soil in the solid load of Taiwanese rivers (Hilton et al., 2008,
Table 1. Average composition of fluvial OC in rivers draining the eastern and western flanks of Taiwan (Table S1) and the average input assuming approximately equal input of sediment from both sides of the mountain range (Dadson et al., 2003; Kao and Milliman, 2008).

\begin{tabular}{lcccrcrc}
\hline & $n$ & $\begin{array}{r}\mathrm{C}_{\text {org }} \\
(\%)\end{array}$ & SD & $\begin{array}{r}\delta^{13} \mathrm{C}_{\text {org }} \\
(\% \circ)\end{array}$ & SD & $\begin{array}{r}\Delta^{14} \mathrm{C}_{\text {org }} \\
(\%)\end{array}$ & SD \\
\hline Average west & 20 & 0.43 & 0.16 & -25.5 & 0.7 & -646 & 237 \\
Average east & 28 & 0.45 & 0.27 & -24.4 & 1.1 & -677 & 271 \\
Average & 48 & 0.44 & 0.22 & -24.9 & 0.9 & -661 & 254 \\
\hline
\end{tabular}

2012) and elsewhere (Clark et al., 2013; Smith et al., 2013) because the output of the mixing analysis is defined as not fossil (Hilton et al., 2010). Here, $\mathrm{OC}_{\text {biosphere }}$ is used to refer to the same component of OC termed "non-fossil" in previous work (Hilton et al., 2012) because of its clear reference to the source of $\mathrm{OC}$ from the terrestrial biosphere.

\section{Results}

\subsection{Composition of terrestrial OC exported to the ocean}

Particulate $\mathrm{OC}$ in suspended sediments from the major rivers in Taiwan (Fig. 1) had an average $\mathrm{C}_{\text {org }}=0.4 \pm 0.2 \%( \pm \mathrm{SD}$ Table 1), which is at the lower end of values measured in rivers worldwide (Meybeck, 1982; Stallard, 1998) but is consistent with previous measurements on Taiwanese rivers (Kao and Liu, 1996, 2000; Hilton et al., 2008, 2010) and measurements from mountain rivers elsewhere (Komada et al., 2004; Leithold et al., 2006; Clark et al., 2013; Smith et al., 2013). The particulate OC was radiocarbon depleted and ${ }^{13} \mathrm{C}$-depleted, with a mean $\Delta{ }^{14} \mathrm{C}_{\text {org }}=-661 \pm 254 \%$ and $\delta^{13} \mathrm{C}_{\text {org }}=-24.9 \pm 0.9 \%$ o for the rivers studied here (Table 1 ). The range in isotopic composition of terrestrial OC define a triangular domain between $\Delta^{14} \mathrm{C}_{\text {org }}$ and $\delta^{13} \mathrm{C}_{\text {org }}$ (Fig. 2a) and the measured values are consistent with previous measurements on suspended sediments from Taiwan (Kao and Liu, 2000; Hilton et al., 2008, 2010).

\subsection{Composition of marine OC}

The sediments collected from the trap in the Gaoping Canyon accumulated during Typhoon Kalmaegi (17 July 2008), as constrained by the timing discs deployed by the sediment trap. At that time, SSC in the Gaoping River reached $>20 \mathrm{~g} \mathrm{~L}^{-1}$ the day after the flood peak. Based on past records of $Q_{\mathrm{w}}$ and SSC (Dadson et al., 2005; Kao and Milliman, 2008), it is highly likely that the Gaoping River surpassed $\mathrm{SSC}=40 \mathrm{~g} \mathrm{~L}^{-1}$ necessary for hyperpycnal discharge in this region during Typhoon Kalmaegi. This is consistent with the very high throughput of sediment in the canyon during the event (Liu et al., 2012). Particulate OC samples from the trap have an average $\mathrm{C}_{\mathrm{org}}=0.5 \pm 0.3 \%(n=12)$, which is within a standard deviation of the mean of western river samples 

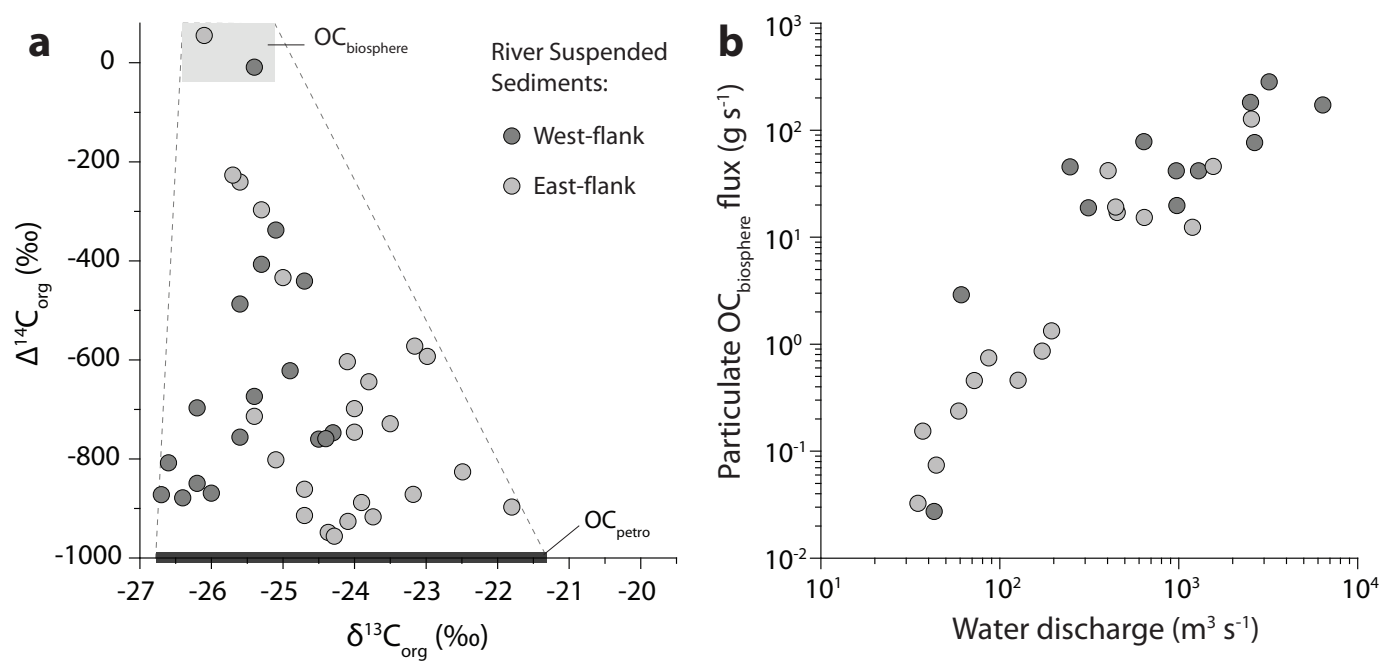

Figure 2. Isotopic compositions and flux of particulate OC eroded from the terrestrial biosphere $\left(\mathrm{OC}_{\text {biosphere }}\right)$ for Taiwan's rivers. (a) Stable and radioactive isotope compositions of organic carbon $\left(\delta^{13} \mathrm{C}_{\mathrm{org}}\right.$ and $\Delta^{14} \mathrm{C}_{\mathrm{org}}, \%$ o ) of suspended sediments from rivers in Taiwan. Analytical errors are smaller than the point size. Samples from catchments draining the two flanks of the mountain belt define a mixing domain between organic carbon from the terrestrial biosphere $\left(\mathrm{OC}_{\text {biosphere }}\right)$ and petrogenic $\mathrm{OC}\left(\mathrm{OC}_{\text {petro }}\right)$ from bedrocks. (b) Instantaneous particulate flux of $\mathrm{OC}_{\text {biosphere }}\left(\mathrm{g} \mathrm{s}^{-1}\right)$ as a function of water discharge during floods in the sampled catchments, demonstrating a strong hydrological control on $\mathrm{OC}_{\text {biosphere }}$ export.

$\left(\mathrm{C}_{\text {org }}=0.43 \pm 0.16 \%, n=20\right)$ and similar to previous measurements in the canyon (Kao et al., 2006). When we include the core samples collected from the canyon following Typhoon Morakot, all of the marine sediments from the Gaoping Canyon $(n=15)$ have a mean $\mathrm{C}_{\mathrm{org}}=0.6 \pm 0.4 \%$, which is only slightly higher than the terrestrial OC (Fig. 3b). Both sets of Gaoping Canyon samples were radiocarbon-depleted (Table S2) and their $\delta^{13} \mathrm{C}_{\text {org }}$ and $\Delta^{14} \mathrm{C}_{\text {org }}$ values fall into the triangular domain defined by terrestrial OC carried by Taiwanese rivers (Fig. 3a).

Away from direct hyperpycnal river inputs, marine particulates collected from sediment traps in the Okinawa Trough (Fig. 1) all had higher $\delta^{13} \mathrm{C}_{\text {org }}, \Delta{ }^{14} \mathrm{C}_{\text {org }}$ and $\mathrm{C}_{\text {org }}$ values than terrestrial OC and Gaoping Canyon samples (Fig. 4, Table S3). When plotted with seafloor sediments collected from the Okinawa Trough, Taiwan Strait and the Gaoping Shelf (Fig. 1), the samples reveal a significant $(P<0.0001, n=$ 26) positive, linear correlation between $\Delta \Delta^{14} \mathrm{C}_{\text {org }}$ and $\delta^{13} \mathrm{C}_{\text {org }}$ (Fig. 4a). Samples collected from below the sediment water interface on the Gaoping Shelf (Table S3) also plot on this trend, as do Holocene sediments from the Okinawa Trough (Kao et al., 2008). These seafloor sediments and trap samples also define a significant negative correlation $(P=0.003$, $n=26$ ) between $1 / \mathrm{C}_{\text {org }}$ and $\Delta \Delta^{14} \mathrm{C}_{\text {org }}$ (Fig. 5a). A linear trend between isotopes can result from mixing of two dominant sources (a binary mixture), or may reflect a process by which both sets of isotopes are modified (for example by preferential loss of one component of OC). A linear trend between the inverse of concentration and isotope composition may also result from binary mixing, but OC loss can result in a linear trend which is distinct from mixing. The explanation of these trends will be considered in detail in the Discussion.

\section{Discussion}

\subsection{Erosion and transfer of terrestrial OC}

Physical erosion processes occur at very high rates in mountain landscapes. In Taiwan, suspended sediment yields reach $>10000 \mathrm{Mg} \mathrm{km}^{-2} \mathrm{yr}^{-1}$ due to a combination of steep slopes and intense precipitation during tropical cyclones (Dadson et al., 2003; Kao and Milliman, 2008). These factors mean that bedrock landslides are common, delivering clastic sediment to mountain rivers (Hovius et al., 2000). Landslides also erode organic matter from the terrestrial biosphere and supply OC, mixed with clastic sediment, to rivers (Hilton et al., 2008; West et al., 2011). In addition, the high runoff intensity promotes mobilisation of soil organic matter by overland flow processes (Hilton et al., 2012). These previous studies have examined the erosion and transport of $\mathrm{OC}_{\text {biosphere }}$ in detail and estimated rates of $\mathrm{OC}_{\text {biosphere }}$ transfer which rank amongst the highest in the world (Kao and Liu, 1996, 2000; Stallard, 1998; Hilton et al., 2008, 2012). Here we summarize the key findings of this previous work in light of the new ${ }^{14} \mathrm{C}$ data from Taiwan (Fig. 3) and to inform our assessment of the offshore fate of terrestrial OC (Sects. 4.2 and 4.3).

The geomorphic processes occurring in Taiwan can explain the triangular domain in $\Delta^{14} \mathrm{C}_{\text {org }}$ and $\delta^{13} \mathrm{C}_{\text {org }}$ values due to mixing of $\mathrm{OC}_{\text {petro }}$ and $\mathrm{OC}_{\text {biosphere }}$ (Hilton et al., 2010). Radiocarbon depletion in the samples can be accounted for by the input of $\mathrm{OC}_{\text {petro }}$ from bedrock. Due to its geological 

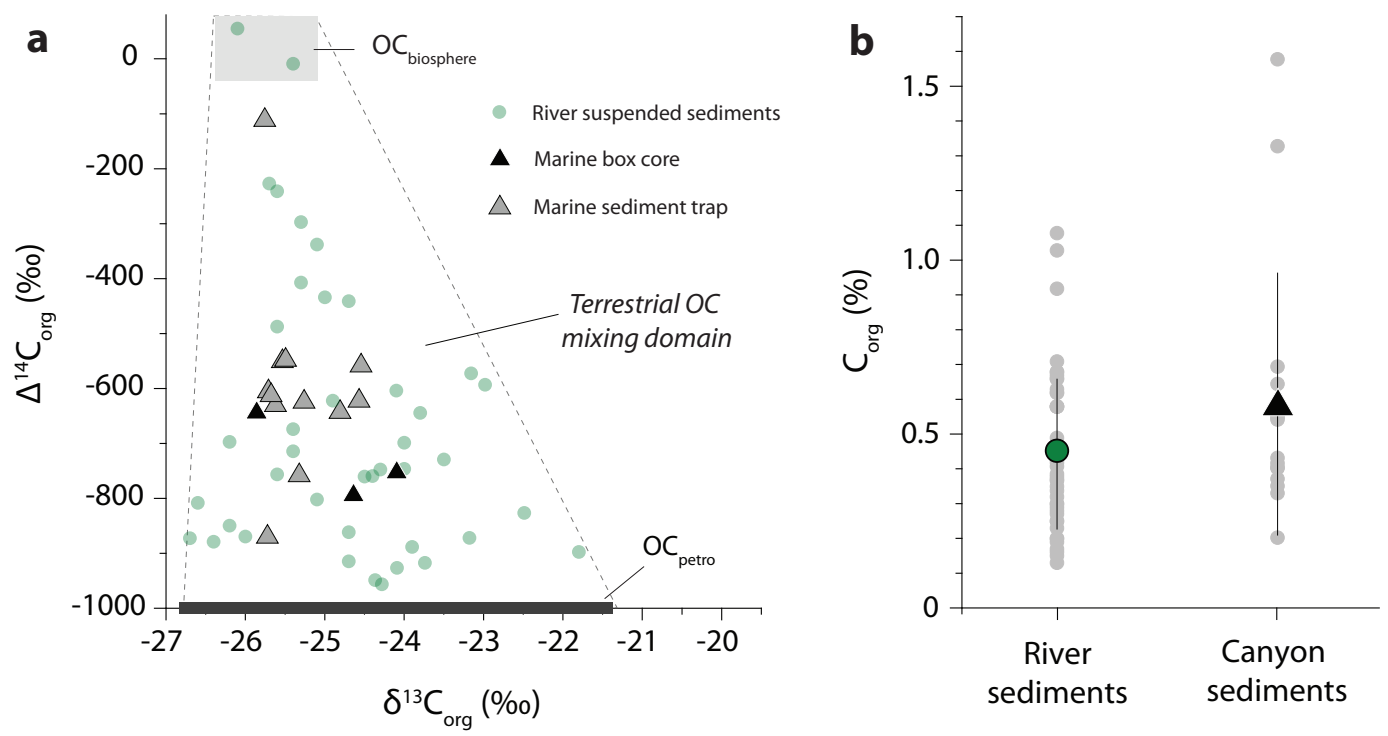

Figure 3. Composition of marine sediments in the Gaoping Canyon (Fig. 1) fed by periodic hyperpycnal flows. (a) Stable and radioactive isotope compositions of organic carbon $\left(\delta^{13} \mathrm{C}_{\text {org }}\right.$ and $\Delta^{14} \mathrm{C}_{\mathrm{org}}, \%$ ) in marine sediments (sediment trap and box core) from the Gaoping Canyon, along with river suspended sediments of Taiwan (as shown in Fig. 2b). (b) Organic carbon concentration $\left(\mathrm{C}_{\mathrm{org}}\right.$, \%), with mean \pm standard deviation shown by large symbol and whiskers for river suspended sediments and canyon sediments (trap and core) from the Gaoping Canyon.

age ( $>50 \mathrm{ka}), \mathrm{OC}_{\text {petro }}$ from Mesozoic-Cenozoic sedimentary rocks has no measurable ${ }^{14} \mathrm{C}$ and so has $\Delta^{14} \mathrm{C}_{\text {org }} \sim-1000 \%$. In addition, $\mathrm{OC}_{\text {petro }}$ input can account for the range in $\delta^{13} \mathrm{C}_{\mathrm{org}}$ values at low $\Delta{ }^{14} \mathrm{C}_{\text {org }}$ in Taiwan (Fig. 2a), where metasedimentary bedrocks have $\delta^{13} \mathrm{C}_{\text {org }}$ values ranging from $-25 \%$ o up to $-20 \%$ (Hilton et al., 2010). Hilton et al. (2010) reported that rivers draining the east flank of Taiwan can have higher $\delta^{13} \mathrm{C}_{\text {org }}$ values $\left({ }^{13} \mathrm{C}\right.$-enriched) than those draining the west due to different bedrock geology leading to variable $\mathrm{OC}_{\text {petro }}$ composition. The ${ }^{14} \mathrm{C}$-depleted samples are consistent with this observation (Fig. 2a). In contrast, when values of $\Delta^{14} \mathrm{C}_{\text {org }}$ are higher $\left({ }^{14} \mathrm{C}\right.$-enriched $)$, the stable isotope composition is much less variable (Fig. 2a). The $\delta^{13} \mathrm{C}_{\text {org }}$ values are similar to those of $\mathrm{C} 3$ biomass and soil in Taiwanese mountain forest (Kao and Liu, 2000; Hilton et al., 2013). Previous work has suggested that surface soil horizons in Taiwan have a $\mathrm{C}_{\text {org }}$-weighted average $\Delta{ }^{14} \mathrm{C}_{\text {org }} \sim 0 \%$ (Hilton et al., 2008), reflecting the high rates of OC export in the source area which can act to limit soil age (Hilton et al., 2012). Addition of this young $\mathrm{OC}_{\text {biospehre }}$ can explain the range of $\Delta \Delta^{14} \mathrm{C}_{\text {org }}$ values in the suspended sediments (Fig. 2a). However, we note that an expanded soil data set (Hilton et al., 2013) shows that older soil $\mathrm{OC}_{\text {biospehre }}\left(\Delta^{14} \mathrm{C}_{\text {org }} \sim-100 \%\right)$ may be present in this mountain belt. Its volumetric contribution to the river load is difficult to assess because the ${ }^{14} \mathrm{C}$ depletion in the bulk suspended sediment is dominated by $\mathrm{OC}_{\text {petro }}$ inputs (Fig. 2a). We suggest that organic-compound specific ${ }^{14} \mathrm{C}$ measurements may shed light on the erosion and transport of any aged soil OC (e.g. Galy and Eglinton, 2011).
The rapid fluvial transit times in Taiwan, combined with young soils (Hilton et al., 2008), mean that the ${ }^{14} \mathrm{C}$ content of particulate $\mathrm{OC}$ can provide a proxy for $\mathrm{OC}_{\text {petro }}$ input to the suspended load, in analogy with work from other small mountain river systems (e.g. Komada et al., 2004; Leithold et al., 2006; Clark et al., 2013). Taking $\Delta{ }^{14} \mathrm{C}_{\text {org }}$ values for bedrock $\left(-1000 \%\right.$ ) and $\mathrm{OC}_{\text {biosphere }}$ based on the $\mathrm{C}_{\text {org }}$ weighted mean of 10 surface soil samples of $0 \%$ (Hilton et al., 2008) we have used an end member mixing model to quantify the fraction of $\mathrm{OC}_{\text {biosphere }}$ in river suspended sediments. If older soil organic matter $\left(\Delta^{14} \mathrm{C}_{\text {org }}<0 \%\right.$ ) is more important than the existing soil samples suggest (Hilton et al., 2008, 2013), the estimated $\mathrm{OC}_{\text {biosphere }}$ component will be conservative. Results indicate that the flux of particulate $\mathrm{OC}_{\text {biosphere }}\left(\mathrm{g} \mathrm{s}^{-1}\right)$ increases with water discharge (Fig. 2b). This confirms a strong climatic control on the erosion and fluvial transfer of $\mathrm{OC}_{\text {biosphere }}$ highlighted in several Taiwanese catchments using a slightly different method for quantifying the mixing of $\mathrm{OC}_{\text {petro }}$ and $\mathrm{OC}_{\text {biosphere }}$ (Hilton et al., 2010; Hilton et al., 2012). It reflects the activation of erosion processes (overland flow, gully incision, landslides) during heavy precipitation and supply of $\mathrm{OC}_{\text {biosphere }}$ and sediment to rivers when their transport capacity is high (Hilton et al., 2008, 2012). This mechanism is not unique to Taiwan, and has been observed elsewhere when flux and OC source data are both available in tropical (Bass et al., 2011; Clark et al., 2013; Lloret et al., 2013) and temperate mountain forests (Hatten et al., 2012; Smith et al., 2013). A consequence of this behaviour is that flood events can dominate the particulate flux, with $80-90 \%$ of the decadal transfer of $\mathrm{OC}_{\text {biosphere }}$ 
by the Liwu River found to occur during cyclonic storms with return times $>1 \mathrm{yr}$ (Hilton et al., 2008). The importance of storm-triggered floods for particulate transfer appears to be a wider feature of small mountain rivers (Townsend-Small et al., 2008; Bass et al., 2011; Lloret et al., 2013).

The suspended sediment samples provide good constraint on the compositional range of terrestrial OC delivered directly to the ocean by hyperpycnal plumes. In addition, because our sample set captures particulate OC from across the mountain belt (Fig. 1), we can assess the likely composition of hypopycnal inputs, which may be expected to be a mixture of sediments sourced from individual river catchments. The average of all river samples (Table 1) is $\mathrm{C}_{\text {org }}=0.44 \pm 0.22 \%, \delta^{13} \mathrm{C}_{\text {org }}=-24.9 \pm 0.9 \%, \Delta^{14} \mathrm{C}_{\text {org }}=$ $-661 \pm 254 \%$. The $\Delta^{14} \mathrm{C}_{\text {org }}$ value suggests that $\mathrm{OC}_{\text {biosphere }}$ contributes $\sim 30 \%$ of the total particulate OC on average with $\mathrm{OC}_{\text {petro }}$ making up the remaining fraction, in agreement with previous estimates from Taiwan (Kao and Liu, 2000; Hilton et al., 2008; Hilton et al., 2010).

\subsection{Fate of terrestrial OC offshore Taiwan: hyperpycnal inputs}

To constrain the transfer of terrestrial OC to the marine environment, we can use the isotopic and elemental composition of samples from marine sediment traps offshore Taiwan. To assess the longer-term preservation, the composition of seafloor sediments and longer cores can be used. The $\Delta^{14} \mathrm{C}_{\text {org }}$ and $\delta^{13} \mathrm{C}_{\text {org }}$ values of terrestrial $\mathrm{OC}$ exported by rivers from Taiwan (Fig. 2a) have been characterized more thoroughly than any previous study (Kao and Liu, 1996; Hilton et al., 2008). Recent marine OC can be distinguished from terrestrial OC due to its higher $\delta^{13} \mathrm{C}_{\text {org }}$ and $\Delta^{14} \mathrm{C}_{\text {org }}$ values (Hsu et al., 2006). However, the assessment of OC provenance is not the same as quantifying preservation. To do that, we have used $\mathrm{C}_{\text {org }}$ values of the sediments because $\mathrm{C}_{\text {org }}$ values are sensitive to changes in the association of $\mathrm{OC}$ with clastic particles and can track OC loss (e.g. Galy et al., 2007a; Blair and Aller, 2012; Cathalot et al., 2013). Our investigation of marine samples does not extend to the very deep ocean waters offshore the east coast of Taiwan (Fig. 1). However, $\mathrm{O}_{2}$ concentrations in the unsampled region, which reach water depths $>4000 \mathrm{~m}$, are low and comparable to those in the Bay of Bengal at $2000 \mathrm{~m}$ water depth (Garcia et al., 2010). OC preservation may be higher in these unsampled areas due to the lower oxidation potential of these deep waters (e.g. Cai and Sayles, 1996; Galy et al., 2007a) than the sites which form the focus of our study (Fig. 1). As a result, our estimates of terrestrial OC preservation efficiency may be conservative.

To assess the fate of terrestrial OC delivered to the ocean by rivers during hyperpycnal discharges, we have examined OC collected by the sediment trap moored in the channel thalweg of the Gaoping Canyon, fed by the Gaoping River (Fig. 1). The sediments trapped during the passage of Typhoon Kalmaegi (17 July 2008) had a range in
$\Delta^{14} \mathrm{C}_{\mathrm{org}}$ and $\delta^{13} \mathrm{C}_{\mathrm{org}}$ values, consistent with the mixture of terrestrial $\mathrm{OC}_{\text {petro }}$ and $\mathrm{OC}_{\text {biosphere }}$ observed in river sediments (Fig. 3a), with an average $\mathrm{C}_{\text {org }}$ very close to the river samples (Fig. 3b). These observations suggest that loss of terrestrial OC during transfer to mesopelagic depths $(\sim 600 \mathrm{~m})$ during this hyperpycnal delivery event has been negligible. The trapped sediment included a "young" organic rich subsample $\left(\mathrm{C}_{\text {org }}=1.6 \%, \Delta{ }^{14} \mathrm{C}_{\text {org }}=-112 \%\right.$, Fig. $\left.3 \mathrm{~b}\right)$ with some shredded woody debris visible to the naked eye and up to $\sim 1 \mathrm{~cm}$ in size (see also Fig. 4 in Liu et al., 2012). Samples collected from the floor of the Gaoping Canyon after Typhoon Morakot also lie within the terrestrial mixing domain (Fig. 3a). Their $\mathrm{C}_{\text {org }}$ values also imply little evidence for terrestrial OC loss (Fig. 3b). Thus, we have found that, contrary to a previous study (Kao et al., 2006), loss of $\mathrm{OC}_{\text {biosphere }}$ (which would systematically lower $\Delta^{14} \mathrm{C}_{\text {org }}$ and $\mathrm{C}_{\text {org }}$ ) is not consistent with the data. Together, the trap and core samples suggest efficient transfer to surface sediments and preservation in the sub-surface $(\sim 100 \%)$ of terrestrial OC (both $\mathrm{OC}_{\text {biosphere }}$ and $\mathrm{OC}_{\text {petro }}$ ) in a submarine canyon fed by hyperpycnal flows. While the fate of terrestrial OC transported deeper down the canyon (e.g. Carter et al., 2012) remains to be assessed, the low $\mathrm{O}_{2}$ levels (Garcia et al., 2009) and high accumulation rates (Huh et al., 2009) are likely to promote longer-term OC burial.

Moreover, it appears that the natural buoyancy of some macro-particles of $\mathrm{OC}_{\text {biosphere }}$ can be overcome during hyperpycnal flood discharges, as observed in modern sourceto-sink settings elsewhere (Leithold and Hope, 1999) and in the geological record (e.g. Saller et al., 2006). This suggests that the density of the turbid river plume may be high enough to effectively sequester woody debris carried in the sand fraction, while coarser woody material (e.g. logs) float upon discharge to the ocean (West et al., 2011). In addition, water logging of sand-sized woody debris may occur prior to entrainment or during transport, as observed in the sand-sized bedload of larger fluvial systems (Bianchi et al., 2007). In the short mountain rivers of Taiwan, it is unclear whether this mechanism operates; the observation warrants further investigation of the transport of macro-particles of $\mathrm{OC}_{\text {biosphere }}$ in mountain rivers (e.g. Turowski et al., 2013).

\subsection{Fate of terrestrial OC offshore Taiwan: hypopycnal inputs}

The fate of terrestrial OC away from direct hyperpycnal inputs can be examined using marine samples collected from a wider region around Taiwan (Fig. 1). The core and trap samples from the Okinawa Trough, Taiwan Strait and the Gaoping Shelf displayed significant trends between $\Delta^{14} \mathrm{C}_{\text {org }}$ and $\delta^{13} \mathrm{C}_{\text {org }}$ (Fig. 4a), which distinguish them from the Gaoping Canyon samples (Fig. 3a). However, compared to recent marine OC $\left(\mathrm{OC}_{\text {marine }}\right)$ from the western Pacific (Hsu et al., 2006; Table 2), they were variably depleted in both ${ }^{13} \mathrm{C}$ and ${ }^{14} \mathrm{C}$ (Fig. 4a). The values cannot be explained by aging and 

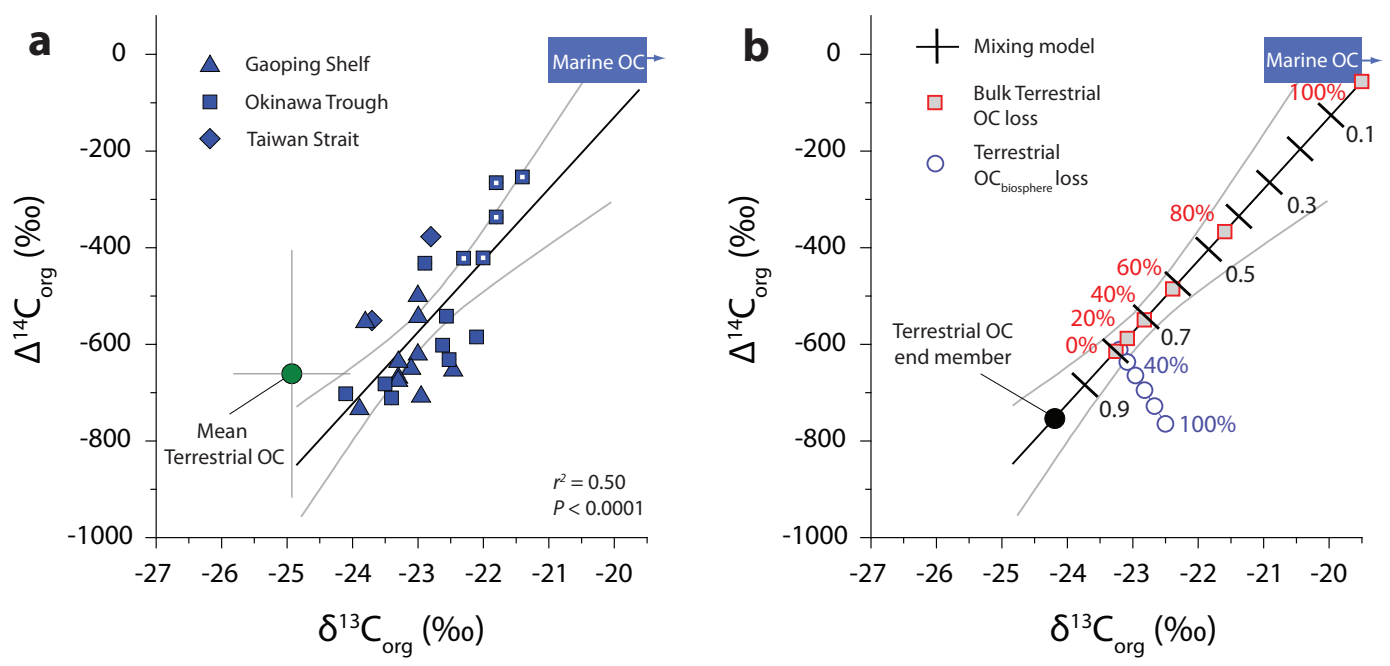

Figure 4. Stable and radioactive isotopic compositions of organic carbon $\left(\delta^{13} \mathrm{C}_{\mathrm{org}}\right.$ and $\left.\Delta^{14} \mathrm{C}_{\mathrm{org}}, \%_{0}\right)$ in marine sediments offshore Taiwan fed by dispersive terrestrial inputs (Fig. 1). (a) White dots denote samples from the trap moorings. The mean terrestrial OC composition delivered by rivers (green circle, whiskers \pm SD) and the expected composition of recent marine OC (blue box) are shown. The samples display a positive linear relationship (black line, with $95 \%$ confidence intervals in grey). (b) Linear relationship displayed in the samples along with the isotopic composition of OC predicted by (i) mixing marine OC and terrestrial OC (black line and dashes with fraction of terrestrial OC); (ii) loss of terrestrial $\mathrm{OC}_{\text {biosphere }}$ starting at fraction terrestrial $\mathrm{OC}=0.8$ (circles with \% loss); and (iii) bulk terrestrial OC loss (squares with \% loss).

Table 2. Compositions used in the mixing and terrestrial OC loss models.

\begin{tabular}{lrrr}
\hline & $\begin{array}{r}\Delta^{14} \mathrm{C}_{\text {org }} \\
(\% o)\end{array}$ & $\begin{array}{r}\delta^{13} \mathrm{C}_{\text {org }} \\
(\% \circ)\end{array}$ & $\begin{array}{r}\mathrm{C}_{\text {org }} \\
(\%)\end{array}$ \\
\hline $\mathrm{OC}_{\text {marine }}$ & $-59^{\mathrm{a}}$ & -19.5 & 30 \\
River OC & $-753^{\mathrm{b}}$ & $-24.2^{\mathrm{b}}$ & $0.48^{b}$ \\
River OC & -1000 & $-23.5^{\mathrm{b}}$ & - \\
River $^{\mathrm{b}} \mathrm{OC}_{\text {biosphere }}$ & $0^{\mathrm{c}}$ & $-26.0^{\mathrm{b}}$ & - \\
\hline
\end{tabular}

${ }^{a}$ From open marine surface trap samples (Hsu et al., 2006). ${ }^{\text {b }}$ Indicative values used to examine the nature of trends in the data (Figs. $4 \mathrm{~b}$ and $5 \mathrm{~b}$ ) informed by the measured compositions (Table 1, Figs. 2a, 4a and 5a). ${ }^{\mathrm{c}}$ Measured mean of bulk soils from Taiwan weighted by organic carbon content (Hilton et al., 2008).

re-suspension of $\mathrm{OC}_{\text {marine }}$ because this ${ }^{14} \mathrm{C}$-depletion only results in $\Delta{ }^{14} \mathrm{C}_{\text {org }}$ values of approximately $-50 \%$ o to $-100 \%$ o in this setting (Hwang et al., 2010). Instead, the linear trend between $\Delta^{14} \mathrm{C}_{\text {org }}$ and $\delta^{13} \mathrm{C}_{\text {org }}$ values may be indicative of binary mixing between end members with distinct compositions (Komada et al., 2004; Clark et al., 2013). The best fit to the data intersects the average of measured riverine OC (itself a mixture of $\mathrm{OC}_{\text {petro }}$ and $\mathrm{OC}_{\text {biosphere }}$ ) and the values expected for recent $\mathrm{OC}_{\text {marine }}$ (Fig. 4a). Thus, the first order pattern in the samples collected away from direct hyperpycnal inputs can be explained by mixing $\mathrm{OC}_{\text {marine }}$ with terrestrial $\mathrm{OC}$.

However, loss of terrestrial $\mathrm{OC}$ during marine transfer and deposition may have caused $\Delta \Delta^{14} \mathrm{C}_{\text {org }}$ and $\delta^{13} \mathrm{C}_{\text {org }}$ values to evolve towards the composition of $\mathrm{OC}_{\text {marine }}$. The linear trend suggests that if this loss has occurred, it has done so in a relatively short period of time, because otherwise $\Delta^{14} \mathrm{C}_{\text {org }}$ would vary with time and produce a non-linear relationship with $\delta^{13} \mathrm{C}_{\text {org }}$. To assess the possible loss of terrestrial OC in the marine realm, we model a scenario of instantaneous loss (see Supplement). The results indicate that preferential loss of $\mathrm{OC}_{\text {biosphere }}$ (e.g. Kao et al., 2006; Cathalot et al., 2013) produces a negative, linear trend between $\Delta^{14} C_{\text {org }}$ and $\delta^{13} \mathrm{C}_{\text {org }}$ (Fig. 4b), which is not consistent with the data. On the other hand, bulk loss of terrestrial OC (both $\mathrm{OC}_{\text {biosphere }}$ and $\mathrm{OC}_{\text {petro }}$ ) can produce the observed positive, linear trend between $\Delta{ }^{14} \mathrm{C}_{\text {org }}$ and $\delta^{13} \mathrm{C}_{\text {org }}$ (Fig. $4 \mathrm{~b}$ ).

To constrain whether mixing or loss is the dominant control on the isotopic composition of the marine samples, we have turned to $\mathrm{C}_{\text {org }}$. The model of bulk terrestrial OC loss, which can explain the $\Delta^{14} \mathrm{C}_{\text {org }}$ and $\delta^{13} \mathrm{C}_{\text {org }}$ values (Fig. $4 \mathrm{~b}$ ), cannot reproduce the negative linear relationship between $1 / \mathrm{C}_{\text {org }}$ and $\Delta \Delta^{14} \mathrm{C}_{\text {org }}$. The modelled bulk terrestrial OC loss results in a trend which is perpendicular to that observed in the samples (Fig. 5b). Thus, it appears that the patterns in the data are not consistent with either selective (i.e. $\mathrm{OC}_{\text {biosphere }}$, Fig. 4 b) or pervasive (i.e. $\mathrm{OC}_{\text {biosphere }}$ and $\mathrm{OC}_{\text {petro }}$, Fig. 5b) loss of terrestrial OC. Thus, the only way to account for the first order trends in the measured isotopic and elemental composition of OC $\left(\delta^{13} \mathrm{C}_{\text {org }}, \Delta \Delta^{14} \mathrm{C}_{\text {org }}\right.$ and $\left.\mathrm{C}_{\text {org }}\right)$ in the offshore sediments is through a mixture of $\mathrm{OC}_{\text {marine }}$ and riverine $\mathrm{OC}$ (itself a mixture of $\mathrm{OC}_{\text {petro }}$ and $\mathrm{OC}_{\text {biosphere }}$ ) (Figs. 4 and 5).

The scatter around the linear trends in the data may reflect second-order temporal (or spatial) variations in the $\Delta^{14} C_{\text {org }}$, 

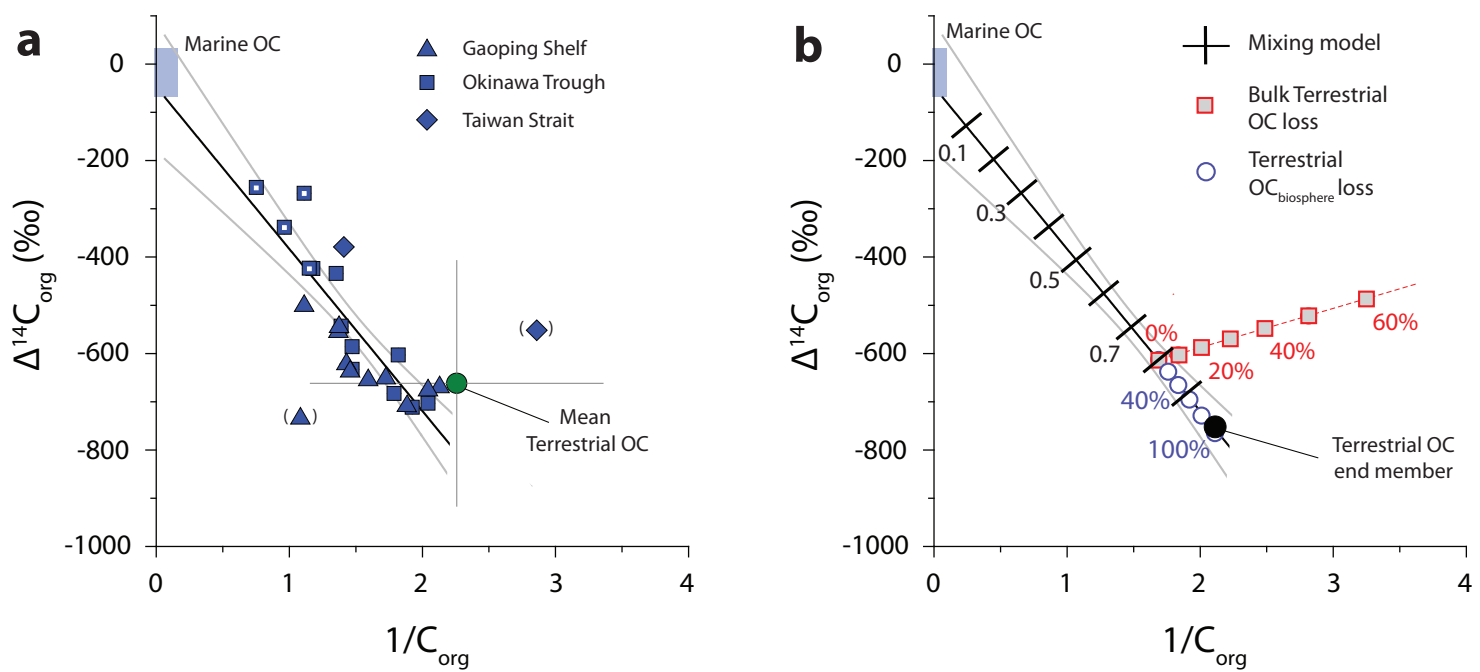

Figure 5. Radiocarbon contents of organic carbon (expressed as $\Delta{ }^{14} \mathrm{C}_{\text {org }}$, \%o) versus the inverse of OC concentration $\left(1 / \mathrm{C}_{\text {org }}\right)$ in marine sediments offshore Taiwan fed by dispersive terrestrial inputs (Fig. 1) with symbols as in Fig. 4. (a) All samples show a negative relationship between the variables $(r=-0.6 ; P=0.003)$ with a linear fit to all samples apart from those in brackets shown by the blank line $\left(r^{2}=0.7\right.$; $P=0.0001$, grey line is the $95 \%$ confidence interval). (b) Linear relationship displayed in the samples along with the OC content predicted by (i) mixing marine OC and terrestrial OC (black line and dashes with fraction of terrestrial OC); (ii) loss of $\mathrm{OC}_{\text {biosphere }}$ (starting at fraction terrestrial $\mathrm{OC}=0.8$, circles with $\%$ loss); and (iii) bulk terrestrial OC loss (squares with $\%$ loss).

$\delta^{13} \mathrm{C}_{\text {org }}$ and $\mathrm{C}_{\text {org }}$ values of the marine and terrestrial OC end members (Table 1), which can explain the sample compositions. However, the scatter may also reflect some terrestrial OC loss. The instantaneous loss model provides constraint on the percentage of terrestrial OC loss, which is compatible with the variability around the linear trends (Fig. 5). For bulk OC loss, the scatter corresponds to $\sim 20 \%$ loss (Fig. 5 b). To acknowledge the uncertainty on this value, and to provide a conservative estimate of terrestrial OC burial efficiency, we suggest $<30 \%$ loss (i.e. preservation efficiency $>70 \%$ ) has occurred in these deposits. Note that this sample set is dominated by surface marine sediments (Table S3) and so the preservation efficiency refers to the land-to-ocean transfer and deposition of terrestrial $\mathrm{OC}_{\text {biosphere }}$ and $\mathrm{OC}_{\text {petro }}$. However, sub-surface sediments from the Gaoping Shelf and the Holocene sediments from the Okinawa Trough (Table S3) are consistent with the trends (Figs. 4a and 5a). While the limited number of these subsurface samples $(n=7)$ makes it difficult to draw irrefutable conclusions, it appears that high preservation efficiencies are also a feature of sedimentary burial on longer timescales in this setting (Kao et al., 2008).

Efficient preservation of terrestrial $\mathrm{OC}_{\text {biosphere }}$ and $\mathrm{OC}_{\text {petro }}$ in both hyperpycnal and hypopycnal marine sediments (Figs. 3, 4 and 5) is consistent with the high sedimentation rates in the deep ocean basins surrounding Taiwan, which result from the tectonic and climate setting. Sedimentation rates in the southern Okinawa Trough reach $>1 \mathrm{~mm} \mathrm{yr}^{-1}$, sustained by fluvial sediment delivery (Hsu et al., 2006). Indeed, if the total suspended sediment flux of $\sim 380 \mathrm{Tg} \mathrm{yr}^{-1}$ (Dadson et al., 2003) is mostly deposited within $\sim 100 \mathrm{~km}$ of the coast (over $\sim 150000 \mathrm{~km}^{2}$ ), then the average sedimentation rate would be $\sim 2 \mathrm{~mm} \mathrm{yr}^{-1}$ (density of $2.2 \mathrm{~g} \mathrm{~cm}^{-3}$ ). The rapid accumulation of clastic sediment limits the time over which OC is exposed to $\mathrm{O}_{2}$ (Burdige, 2005; Galy et al., 2007a). Since the $\mathrm{O}_{2}$ penetration depth in muddy marine sediments is typically on the order of $1-10 \mathrm{~mm}$ (Hedges and Keil, 1995; Cai and Sayles, 1996), OC biosphere deposited offshore Taiwan is probably exposed to $\mathrm{O}_{2}$ for only a matter of years.

Our findings are consistent with marine sediments undergoing rapid accumulation elsewhere, with bulk OC preservation efficiencies of 70-100\% (Galy et al., 2007a; Blair and Aller, 2012). These tend to exceed terrestrial organic carbon preservation rates in other depositional settings (Burdige, 2005; Blair and Aller, 2012). Unlike steep mountain rivers, large river deltas on passive margins can experience successive resuspension and deposition episodes within mobile muds (e.g. the Amazon Delta). In these systems, marine organic material can be entrained into mobile deposits, driving early diagenetic reactions and facilitating loss of refractory terrestrial $\mathrm{OC}$ during sedimentary refluxing and suboxic diagenesis (Aller, 1998; Aller and Blair, 2006). While conditions in large rivers on passive margins can promote rapid export and deposition of marine OC (Bianchi et al., 2006), resuspension and re-working of sediments on shallow-sloping deltas can also promote incineration of terrestrial OC (Aller et al., 1996, 2008; Aller and Blair, 2006), even following a rapid sediment accumulation event (Sampere et al., 2008). In contrast, apart from the $\sim 100 \mathrm{~m}$ deep Taiwan Strait (Fig. 1), which may be analogous to some of these passive margin 
settings, rivers export materials to deep basins around the island. The rapid accumulation rates offshore Taiwan and the delivery of terrestrial $\mathrm{OC}$ to water depths $>500 \mathrm{~m}$ in $\mathrm{O}_{2}$ poor waters (Garcia et al., 2009) are conditions more analogous to the Bengal Fan system, where terrestrial OC burial efficiencies are also very high (Galy et al., 2007a).

\section{Implications for the global carbon cycle}

After accounting for addition of terrestrial $\mathrm{OC}_{\text {petro }}$ and $\mathrm{OC}_{\text {marine }}$ to the offshore sediments (e.g. Fig. 4), we can now assess how the erosion of terrestrial biomass $\left(\mathrm{OC}_{\text {biosphere }}\right)$ drives sequestration of atmospheric $\mathrm{CO}_{2}$. Our findings suggest that in the Taiwan sediment routing system, rivers deliver sediments which contain on average $0.15 \%$ of terrestrial $\mathrm{OC}_{\text {biosphere }}$ (average $\mathrm{C}_{\text {org }} \times$ average fraction of $\left.\mathrm{OC}_{\text {biosphere }}\right)$ in hypo- and hyperpycnal river plumes. Given the suspended sediment flux from Taiwan to the ocean of $384 \mathrm{Tg} \mathrm{yr}^{-1}$ (Dadson et al., 2003; Dadson et al., 2005), this abundance of $\mathrm{OC}_{\text {biosphere }}$ and the estimated preservation efficiencies of terrestrial OC of $>70 \%$ (see Sect. 4.2), we calculate an $\mathrm{OC}_{\text {biosphere }}$ burial flux of $0.5-0.6 \mathrm{TgC} \mathrm{yr}^{-1}$ in basin fills derived from Taiwan. This may be a lower bound if material coarser than $\sim 500 \mu \mathrm{m}$ (i.e. large woody debris, whose fate remains poorly constrained) contributes importantly to $\mathrm{OC}_{\text {biosphere }}$ transfer and burial (West et al., 2011). Normalized over Taiwan's mountain island surface area $\left(35980 \mathrm{~km}^{2}\right)$, this estimated flux represents an $\mathrm{OC}_{\text {biosphere }}$ burial yield of $13-16 \mathrm{MgC} \mathrm{km}^{-2} \mathrm{yr}^{-1} \cdot \mathrm{CO}_{2}$ sequestration associated with physical erosion of Taiwan appears to be seven times more efficient per $\mathrm{km}^{2}$ than the Himalayan erosion system, which has a burial yield of $\sim 2 \mathrm{MgC} \mathrm{km}^{-2} \mathrm{yr}^{-1}$ (Galy et al., 2007a). Our analysis suggests that the rock-derived $\mathrm{OC}_{\text {petro }}$ is reburied offshore Taiwan at a rate of $0.9-1.1 \mathrm{TgC} \mathrm{yr}^{-1}$, similar to the total $\mathrm{OC}_{\text {petro }}$ buried annually in the Bay of Bengal (Galy et al., 2008). OC $_{\text {biosphere }}$ burial from this single mountain island represents $\sim 1 \%$ of the estimated total annual OC burial in the oceans (Schlunz and Schneider, 2000; Burdige 2005) from only $0.02 \%$ of Earth's continental surface.

The islands of Oceania are sediment production hotspots, with suspended sediment yields typically $>1000 \mathrm{Mg} \mathrm{km}^{-2} \mathrm{yr}^{-1}$ (Milliman and Farnsworth, 2011). The transfer of $\mathrm{OC}_{\text {biosphere }}$ together with clastic sediment may enhance the terrestrial OC burial efficiency (Canfield, 1994; Burdige, 2005; Blair and Aller, 2012), even when materials are delivered by hypopycnal river plumes (see Sect. 4.3). As in Taiwan, terrestrial productivity is high across tropical Oceania and mountain forests contain large stores of $\mathrm{OC}_{\text {biosphere }}$ in standing biomass and soil (Dixon et al., 1994). This permits us to extrapolate our observations to provide a tentative estimate of the $\mathrm{CO}_{2}$ sink associated with the oceanic burial of terrestrial $\mathrm{OC}_{\text {biosphere }}$. Assuming a linear relationship between sediment yield and $\mathrm{OC}_{\text {biosphere }}$ yield (e.g. Hilton et al., 2012), the terrestrial $\mathrm{OC}_{\text {biosphere }}$ content from Taiwan can be combined with the Oceania sediment export of $\sim 7000 \mathrm{Tg} \mathrm{yr}^{-1}$ (Dadson et al., 2003; Milliman and Farnsworth, 2011) and the range of preservation efficiencies obtained here (70-100\%) to estimate a terrestrial $\mathrm{OC}_{\text {biosphere }}$ burial flux of $8-11 \mathrm{TgC} \mathrm{yr}^{-1}$ from the mountain islands of Oceania. This estimate is likely to be conservative because the high sediment yields in Taiwan of $\sim 9000 \mathrm{Mg} \mathrm{km}^{-2} \mathrm{yr}^{-1}$ result in a lower percent of $\mathrm{OC}_{\text {biosphere }}$ in sediments when compared to other mountain rivers (Leithold et al., 2006; Hilton et al., 2012; Clark et al., 2013; Smith et al., 2013). Alternatively, it could be assumed that the $\mathrm{OC}_{\text {biosphere }}$ burial yield from Taiwan (13-16 $\mathrm{MgC} \mathrm{km}^{-2} \mathrm{yr}^{-1}$ ) holds over the Oceania area $\left(2.7 \times 10^{6} \mathrm{~km}^{2}\right)$, giving a terrestrial $\mathrm{OC}_{\text {biosphere }}$

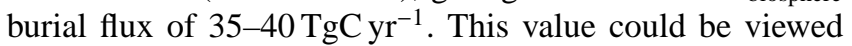
as an upper bound, since the erosion rate of $\mathrm{OC}_{\text {biosphere }}$ from Taiwan may be toward the high end of global values (Hilton et al., 2012). Both estimates do not consider $\mathrm{OC}_{\text {marine }}$ burial associated with these sediments, which could increase $\mathrm{CO}_{2}$ sequestration (Fig. 4a). The lower conservative estimate of $\mathrm{OC}_{\text {biosphere }}$ burial by the erosion of Oceania is globally significant. It represents $\sim 10 \%$ of estimates of the total OC burial in clastic sediments in the oceans (Schlunz and Schneider, 2000; Burdige 2005; Blair and Aller, 2012). Adjustment of these global estimates is warranted and requires further observational constraint on the processes and magnitude of this significant flux in the global carbon cycle.

Our findings suggest that mountain building in Oceania can result in a globally important geological $\mathrm{CO}_{2}$ sink through erosion of the terrestrial biosphere, $\mathrm{OC}_{\text {biosphere }}$ transport by mountain rivers and preservation in marine sediments from hyperpycnal but, importantly, also hypopycnal delivery events (Figs. 4 and 5). This region provides a strong link between tectonic uplift and the carbon cycle, which should influence atmospheric $\mathrm{CO}_{2}$ concentrations on geological timescales. Importantly, $\mathrm{CO}_{2}$ sequestration by erosion of $\mathrm{OC}_{\text {biosphere }}$ should be sensitive to the coverage of terrestrial biomass in the tropics, which is in part moderated by the available supply of $\mathrm{CO}_{2}$ for productivity (Norby et al., 2005). In addition, the amount and variability of runoff control the erosion and export of terrestrial $\mathrm{OC}_{\text {biosphere }}$ (Fig. 2b) and clastic sediment by small mountain rivers (Dadson et al., 2003; Hilton et al., 2008, 2012). Therefore, islands of Oceania have the potential to introduce stabilizing feedbacks in the carbon cycle on geological timescales, which are presently not considered in Earth System models (Berner, 2006; Archer et al., 2010) and not invoked to explain the evolution of atmospheric $\mathrm{CO}_{2}$ levels in the Cenozoic (e.g. Pagani et al., 2009). One aspect of this may be the link between warming ocean temperatures and the occurrence of extreme tropical cyclones in the western Pacific (Elsner et al., 2008) which deliver $\mathrm{OC}_{\text {biosphere }}$ and sediment efficiently to the ocean, as previously hypothesized (Hilton et al., 2008). However, a wider response across Oceania may be felt due to $\mathrm{CO}_{2}$ fertilization of tropical forests (Norby et al., 2005), while ocean 
warming also increases runoff and runoff variability in the tropics away from tropical cyclone influence (Milly et al., 2005). The corresponding increase in terrestrial $\mathrm{OC}_{\text {biosphere }}$ export to the oceans from tropical islands may help to mitigate an increase in greenhouse gas concentration, with enhanced $\mathrm{CO}_{2}$ sequestration by terrestrial $\mathrm{OC}_{\text {biosphere }}$ burial in the ocean. These feedbacks may play a significant role in linking tectonics and climate and their impact on the longterm carbon cycle, all of which deserve further attention.

\section{Supplementary material related to this article is available online at http://www.earth-surf-dynam.net/2/ 127/2014/esurf-2-127-2014-supplement.pdf.}

Acknowledgements. We thank J. Chien (RCEC, AS) for isotope analysis and K. T. Jiann (NSYSU) for offering Taiwan Strait samples, and also V. Galy, D. Burdige and three anonymous referees for their comments, which improved the manuscript. This work was funded by Taiwan (NSC-97-2611-M-001-001-MY2, NSC97-2628-M-001-025, NSC-99-2116-M-001-011), China (NSFC 41176059, 973 Project 2009CB421200 and 2009CB421206, 111 Program B07034) and the Natural Environment Research Council (NERC), UK (Radiocarbon Allocation 1203.1006, 1228.0407).

Edited by: V. Galy

\section{References}

Aller, R. C.: Mobile deltaic and continental shelf muds as suboxic, fluidized bed reactors, Mar. Chem., 61, 143-155, 1998.

Aller, R. C. and Blair, N. E.: Carbon remineralization in the Amazon-Guianas tropical mobile mudbelt: A sedimentary incinerator, Continental Shelf Res., 26, 2241-2259, 2006.

Aller, R. C., Blair, N. E., Xia, Q., and Rude, P. D.: Remineralization rates, recycling and storage of carbon in Amazon shelf sediments, Continental Shelf Res., 16, 753-786, 1996.

Aller, R. C., Blair, N. E., and Brunskill, G. J.: Early diagenetic cycling, incineration, and burial of sedimentary organic carbon in the central Gulf of Papua (Papua New Guinea), J. Geophys. Res., 113, F01S09, doi:10.1029/2006JF000689, 2008.

Archer, D., Eby, M., Brovkin, V., Ridgwell, A., Cao, L., Mikolajewicz, U., Caldeira, K., Matsumoto, K., Munhoven, G., Montenegro, A., and Tokos, K.: Atmospheric lifetime of fossil fuel carbon dioxide, Annu. Rev. Earth Planet. Sci., 37, 117-134, 2009.

Bass, A. M., Bird, M. I., Liddell, M. J., and Nelson, P. N.: Fluvial dynamics of dissolved and particulate organic carbon during periodic discharge events in a steep tropical rainforest catchment, Limnol. Oceanogr., 56, 2282-2292, 2011.

Berner, R. A.: GEOCARBSULF: A combined model for Phanerozoic atmospheric $\mathrm{O}_{2}$ and $\mathrm{CO}_{2}$, Geochim. Cosmochim. Acta, 70, 5653-5664, 2006.

Bianchi, T. S.: The role of terrestrially derived organic carbon in the coastal ocean: A changing paradigm and the priming effect, Proc. Nat. Acad. Sci., 108, 19473-19481, 2011.
Bianchi, T. S., Allison, M. A., Canuel, E. A., Corbett, D. R., McKee, B. A., Sampere, T. P.,Wakeham, S. G., and Waterson, E.: Rapid export of organic matter to the Mississippi Canyon, EOS, 87, 572-573, 2006.

Bianchi, T. S., Galler, J. J., and Allison, M. A.: Hydrodynamic sorting and transport of terrestrially-derived organic carbon in sediments of the Mississippi and Atchafalaya Rivers, Estuarine Coastal Shelf Sci., 73, 211-222, 2007.

Blair, N. E. and Aller, R. C.: The fate of terrestrial organic carbon in the marine environment, Annu. Rev. Mar. Sci., 4, 17.1-17.23, 2012.

Blair, N. E. Leithold, E. L., Ford, S. T., Peeler, K. A., Holmes, J. C., and Perkey D. W.: The persistence of memory: The fate of ancient sedimentary organic carbon in a modern sedimentary system, Geochim. Cosmochim. Acta, 67, 63-73, 2003.

Blair N. E., Leithold, E. L., and Aller, R. C.: From bedrock to burial: the evolution of particulate organic carbon across coupled watershed-continental margin systems, Mar. Chem., 92, 141156, 2004.

Blair, N. E., Leithold, E. L., Brackley, H., Trustrum, N., Page, M., and Childress, L.: Terrestrial sources and export of particulate organic carbon in the Waipaoa sedimentary system: Problems, progress and processes, Mar. Geol., 270, 108-118, 2010.

Buesseler, K. O., Antia, A. N., Chen, M., Fowler, S. W., Gardner, W. D., Gustafsson, O., Harada, K., Michaels, A. F., Rutgers van der Loeff, M., Sarin, M., Steinberg, D. K., and Trull, T.: An assessment of the use of sediment traps for estimating upper ocean particle fluxes, J. Marine Res., 65, 345-416, 2007.

Burdige, D. J.: Burial of terrestrial organic matter in marine sediments: A re-assessment, Global Biogeochem. Cycles, 19, GB4011, doi:10.1029/2004GB002368, 2005.

Cai, W. J. and Sayles, F. L.: Oxygen penetration depths and fluxes in marine sediments, Mar. Chem., 52, 123-131, 1996.

Canfield, D. E.: Factors influencing organic-carbon preservation in marine-sediments, Chem. Geol., 114, 315-329, 1994.

Carter, L., Milliman, J. D., Talling, P. J., Gavey, R. and Wynn R. B.: Near synchronous and delayed initiation of long runout submarine sediment flows from a record-breaking river flood, offshore Taiwan, Geophys. Res. Lett., 39, L12603, doi:10.1029/2012GL051172, 2012.

Cathalot, C., Rabouille, C., Tisnérat-Laborde, N., Toussaint, F., Kerhervé, P., Buscail, R., Loftis, K., Sun, M-Y., Tronczynski, J., Azoury, S., Lansard, B., Treignier, C., Pastor, L., and Tesi, T.: The fate of river organic carbon in coastal areas: a study in the Rhône River delta using multiple isotopic $\left(\delta^{13} \mathrm{C}, \Delta{ }^{14} \mathrm{C}\right)$ and organic tracers, Geochim. Cosmochim. Acta, 118, 33-55, doi:10.1016/j.gca.2013.05.001, 2013.

Clark, K. C., Hilton, R. G., West, A. J., Malhi, Y., Grocke, D. R., Bryant, C. L., Ascough, P. L., Robles, A., and New, M.: New views on old carbon in the Amazon river: Insight from the source of organic carbon eroded from the Peruvian Andes, Geochemistry, Geophysics, Geosystems, 14, 1644-1659, doi:10.1002/ggge.20122, 2013.

Dadson, S. J., Hovius, N., Chen, H., Dade, W. B., Hsieh, M. L., Willett, S. D., Hu, J. C., Horng, M. J., Chen, M. C., Stark, C. P., Lague, D., and Lin, J. C.: Links between erosion, runoff variability and seismicity in the Taiwan orogen, Nature, 426, 648-651, 2003. 
Dadson, S. J., Hovius, N., Pegg, S., Dade, W. B., Horng, M. J., and Chen, H.: Hyperpycnal river flows from an active mountain belt, J. Geophys. Res. Earth Surf., 110, F04016, doi:10.1029/2004JF000244, 2005

Dixon, R. K., Brown, S., Houghton, R. A., Solomon, A. M., Trexler, M. C., and Wisniewski, J.: Carbon pools and flux of global forest ecosystems, Science, 263, 185-190, 1994.

Eglinton, T. I.: Tempestuous transport, Nature Geosci., 1, 727-728, 2008

Elsner, J. B., Kossin, J. P., and Jagger, T. H.: The increasing intensity of the strongest tropical cyclones, Nature, 455, 92-95, 2008.

France-Lanord, C. and Derry, L. A.: Organic carbon burial forcing of the carbon cycle from Himalayan erosion, Nature, 390, 65-67, 1997.

Gaillardet, J. and Galy, A.: Himalaya-Carbon Sink or Source? Science, 320, 1727-1728, 2008.

Gaillardet, J., Dupré, B., Louvat, P., and Allegre, C. J.: Global silicate weathering and $\mathrm{CO}_{2}$ consumption rates deduced from the chemistry of large rivers, Chem. Geol., 159, 3-30, 1999.

Galy, V., France-Lanord, C., Beyssac, O., Faure, P., Kudrass, H., and Palhol, F.: Efficient organic carbon burial in the Bengal fan sustained by the Himalayan erosional system, Nature, 450, 407410. 2007a.

Galy, V., Bouchez, J., and France-Lanord, C.: Determination of total organic carbon content and $\delta^{13} \mathrm{C}$ in carbonate rich detrital sediments, Geostand. Geoanal. Res., 31, 199-207, 2007b.

Galy, V., Beyssac, O., France-Lanord, C., and Eglinton, T. I.: Recycling of graphite during Himalayan erosion: A geological stabilization of carbon in the crust, Science, 322, 943-945, 2008.

Garcia, H. E., Locarnini, R. A., Boyer, T. P., Antonov, J. I., Baranova, O. K., Zweng, M. M., and Johnson, D. R.: World Ocean Atlas 2009, Volume 3: Dissolved oxygen, apparent oxygen utilization, and oxygen saturation. S. Levitus, Ed. NOAA Atlas NESDIS 70, US Government Printing Office, Washington, DC, 344 pp, 2010.

Hatten, J. A., Goñi, M. A., and Wheatcroft, R. A.: Chemical characteristics of particulate organic matter from a small mountainous river in the Oregon Coast Range, USA, Biogeochem., 107, 4366, 2012.

Hayes, J. M., Strauss, K., and Kaufman, A. J.: The abundance of ${ }^{13} \mathrm{C}$ in marine organic matter and isotopic fractionation in the global biogeochemical cycle of carbon during the past $800 \mathrm{Ma}$, Chem. Geol., 161, 103-125, 1999.

Hedges, J. I. and Keil, R. G.: Sedimentary organic matter preservation: An assessment and speculative synthesis, Mar. Chem., 49, 81-115, 1995.

Hilton, R. G., Galy, A., Hovius, N., Chen, M. C., Horng, M. J., and Chen, H.: Tropical-cyclone-driven erosion of the terrestrial biosphere from mountains, Nature Geosci., 1, 759-762, 2008.

Hilton, R. G., Galy, A., Hovius, N., Horng, M. J., and Chen, H.: The isotopic composition of particulate organic carbon in mountain rivers of Taiwan, Geochim. Cosmochim. Acta, 74, 3164-3181, 2010.

Hilton, R. G., Galy, A., Hovius, N., Horng, M. J., and Chen, H.: Efficient transport of fossil organic carbon to the ocean by steep mountain rivers: An orogenic carbon sequestration mechanism, Geology, 39, 71-74, 2011.

Hilton, R. G., Galy, A., Hovius, N., Kao, S. J., Horng, M. J., and Chen, H.: Climatic and geomorphic controls on the erosion of terrestrial biomass from subtropical mountain forest, Global Biogeochem. Cycles, 26, GB3014, doi:10.1029/2012GB004314, 2012.

Hilton, R. G., Galy, A., West, A. J., Hovius, N., and Roberts, G. G.: Geomorphic control on the $\delta^{15} \mathrm{~N}$ of mountain forests, Biogeosciences, 10, 1693-1705, 2013, http://www.biogeosciences.net/10/1693/2013/.

Hovius, N., Stark, C. P., Chu, H. T., and Lin, J. C.: Supply and removal of sediment in a landslide-dominated mountain belt: Central Range, Taiwan, J. Geol., 108, 73-89, 2000.

Hsu, S. C., Kao, S. J., and Jeng, W. L.: Quantitative links among fluvial sediment discharge, hemipelagic trap flux and sediment accumulations and implications for climate change, Deep Sea Res. I, 53, 241-252, 2006

Huh, C. A., Liu, J. T., Lin, H.-L., and Xu, J. P.: Tidal and flood signatures of settling particles in the Gaoping submarine canyon (SW Taiwan) revealed from radionuclide and flow measurements, Mar. Geol., 267, 8-17, 2009.

Hwang, J., Druffel, E. R. M., and Eglinton, T. I.: Widespread influence of resuspended sediments on oceanic particulate organic carbon: Insights from radiocarbon and aluminum contents in sinking particles, Global Biogeochem. Cy., 24, GB4016, doi:10.1029/2010GB003802, 2010.

Kao, S. J. and Liu, K. K.: Particulate organic carbon export from a subtropical mountainous river (Lanyang Hsi) in Taiwan, Limnol. Oceanogr., 41, 1749-1757, 1996.

Kao, S. J. and Liu, K. K.: Stable carbon and nitrogen isotope systematics in a human-disturbed watershed (Lanyang-Hsi) in Taiwan and the estimation of biogenic particulate organic carbon and nitrogen fluxes, Global Biogeochem. Cy., 14, 189-198, 2000.

Kao, S. J. and Milliman, J. D.: Water and sediment discharge from small mountainous rivers, Taiwan: The roles of lithology, episodic events, and human activities, J. Geol., 116, 431-448, 2008.

Kao, S. J., Shiah, F. K, Wang, C. H., and Liu, K. K.: Efficient trapping of organic carbon in sediments on the continental margin with high fluvial sediment input off southwestern Taiwan, Continental Shelf Res., 26, 2520-2537, 2006.

Kao, S. J., Dai, M. H., Wei, K. Y., Blair, N. E., and Lyons, W. B.: Enhanced supply of fossil organic carbon to the Okinawa Trough since the last deglaciation, Paleoceanography, 23 , PA2207, doi:10.1029/2007PA001440, 2008.

Komada, T., Druffel, E. R. M., and Trumbore, S. E.: Oceanic export of relict carbon by small mountainous rivers, Geophys. Res. Lett., 31, L07504, doi:10.1029/2004GL019512, 2004.

Komada, T., Anderson, M. R., and Dorfmeier, C. L.: Carbonate removal from coastal sediments for the determination of organic carbon and its isotopic signatures, $\delta^{13} \mathrm{C}$ and $\Delta^{14} \mathrm{C}$ : Comparison of fumigation and direct acidification by hydrochloric acid, Limnol. Oceanogr., 6, 254-262, 2008.

Leithold, E. L. and Hope, R. S.: Deposition and modification of a flood layer on the Northern California shelf: Lessons from and about the fate of terrestrial particulate organic carbon, Mar. Geol., 154, 183-195, 1999.

Leithold, E. L., Blair, N. E., and Perkey, D. W.: Geomorphologic controls on the age of particulate organic carbon from small mountainous and upland rivers. Global Biogeochem. Cycles, 20, GB3022, doi:10.1029/2005GB002677, 2006 
Liu, J. T., Wang, Y.-H., Yang, R. J., Hsu, R. T., Kao, S.-J., Lin, H.-L., and Kuo, F. H.: Cyclone-induced hyperpycnal turbidity currents in a submarine canyon, J. Geophys. Res., 117, C04033, doi:10.1029/2011JC007630, 2012.

Liu, J. T., Kao, S.-J., Huh, C.-A., and Hung, C.-C.: Gravity flows associated with flood events and carbon burial: Taiwan as instructional source area, Annu. Rev. Mar. Sci., 5, 47-68, 2013.

Lloret, E., Dessert, C., Pastor, L., Lajeunesse, E., Crispi, O., Gaillardet, J., and Benedetti, M. F.: Dynamic of particulate and dissolved organic carbon in small volcanic mountainous tropical watersheds, Chem. Geol., 351, 229-244, doi.org/10.1016/j.chemgeo.2013.05.023, 2013.

Lyons, W. B., Nezat, C. A., Carey, A. E., and Hicks, D. M. Organic carbon fluxes to the ocean from high-standing islands, Geology, 30, 439-442, 2002.

Meybeck, M.: Carbon, nitrogen and phosphorus transport by world rivers, Am. J. Sci., 282, 401-450, 1982.

Milliman, J. D. and Farnsworth, K. L.: River Discharge to the Coastal Ocean: A Global Synthesis, Cambridge University Press, Cambridge, UK, 2011.

Milly, P. C. D., Dunne, K. A., and Vecchia, A. V.: Global pattern of trends in streamflow and water availability in a changing climate, Nature, 438, 347-350, 2005.

Mulder, T. and Syvitski, J. P. M.: Turbidity currents generated at river mouths during exceptional discharges to the world oceans, J. Geol., 103, 285-299, 1995.

Norby, R. J., DeLucia, E. H., Gielen, B., Calfapietra, C., Giardina, C. P., King, J. S., Ledford, J., McCarthy, H. R., Moore, D. J. P., Ceulemans, R., De Angelis, P., Finzi, A. C., Karnosky, D. F., Kubiske, M. E., Lukac, M., Pregitzer, K. S., Scarascia-Mugnozza, G. E., Schlesinger, W. H., and Oren R.: Forest response to elevated $\mathrm{CO}_{2}$ is conserved across a broad range of productivity, PNAS, 102, 18052-18056, 2005.

Pagani, M., Caldeira, K., Berner, R. A., and Beerling, D. J.: The role of terrestrial plants in limiting atmospheric $\mathrm{CO}_{2}$ decline over the past 24 million years, Nature, 460, 85-88, 2009.

Saller, A., Lin, R., and Dunham, J.: Leaves in turbidite sands: The main source of oil and gas in the deep-water Kutei Basin, Indonesia, AAPG Bull., 90, 1585-1608, 2006.

Sampere, T. P., Bianchi, T. S., Wakeham, S. G., and Allison, M. A.: Sources of organic matter in surface sediments of the Louisiana Continental Margin: Effects of primary depositional/transport pathways and Hurricane Ivan, Cont. Shelf Res., 28, 2472-2487, 2008.
Schlünz, B. and Schneider, R. R.: Transport of terrestrial organic carbon to the oceans by rivers: Re-estimating flux and burial rates, Int. J. Earth Sci., 88, 599-606, 2000.

Scott, D. T., Baisden, W. T., Davies-Colley, R., Gomez, B., Hicks, D. M., Page, M. J., Preston, N. J., Trustrum, N. A., Tate, K. R., and Woods, R. A.: Localized erosion affects national carbon budget, Geophys. Res. Lett., 33, L01402, doi:10.1029/2005GL024644, 2006.

Smith, J. C., Galy, A., Hovius, N., Tye, A., Turowski, J. M., and Schleppi, P.: Runoff-driven export of particulate organic carbon from soil in temperate forested uplands, Earth Planet. Sci. Lett., 365, 198-208, 2013.

Sparkes, R. B.: Marine sequestration of particulate organic carbon from mountain belts, Ph.D. thesis, University of Cambridge, Cambridge, UK, 2012.

Stallard, R. F.: Terrestrial sedimentation and the carbon cycle: Coupling weathering and erosion to carbon burial, Global Biogeochem. Cy., 12, 231-257, 1998.

Stuiver, M. and Polach, H. A.: Discussion: Reporting of ${ }^{14} \mathrm{C}$ data, Radiocarbon, 19, 355-363, 1977.

Sundquist, E. T.: The global carbon dioxide budget, Science, 259 , 934-941, 1993.

Townsend-Small, A., McClain, M. E., Hall, B., Noguera, J. L., Llerena, C. A., and Brandes, J. A.: Suspended sediments and organic matter in mountain headwaters of the Amazon River: Results from a 1-year time series study in the central Peruvian Andes, Geochim. Cosmochim. Acta, 72, 732-740, doi:10.1016/j.gca.2007.11.020, 2008.

Turowski, J.M., Badoux, A., Bunte, K., Rickli, C., Federspiel, N. and Jochner, M.: The mass distribution of coarse particulate organic matter exported from an Alpine headwater stream, Earth Surf. Dynam., 1, 1-11, 2013.

West, A. J., Galy, A., and Bickle, M.: Tectonic and climatic controls on silicate weathering, Earth Planet. Sci. Lett., 235, 211-228, 2005.

West, A. J., Lin, C. W., Lin, T. C., Hilton, R. G., Liu, S. H., Chang, C. T., Lin, K. C., Galy, A., Sparkes, R. B., and Hovius, N.: Mobilization and transport of coarse woody debris to the oceans triggered by an extreme tropical storm, Limnol. Oceanogr., 56, 77-85, 2011

Xu, J. P., Swarzenski, P. W., Noble, M. A., and Li, A.-C.: Eventdriven sediment flux in Hueneme and Mugu submarine canyons, southern California, Mar. Geol., 269, 74-88, 2010. 